Black Walden 



\section{Black Walden}

Slavery and Its Aftermath in Concord, Massachusetts

\section{Elise Lemire}

\section{PENN}

UNIVERSITY OF PENNSYLVANIA PRESS

Philadelphia 
Copyright () 2009 Elise Lemire

All rights reserved. Except for brief quotations used for purposes of review or scholarly citation, none of this book may be reproduced in any form by any means without written permission from the publisher.

Published by

University of Pennsylvania Press

Philadelphia, Pennsylvania 19104-4112

Printed in the United States of America on acid-free paper

10987654321

Library of Congress Cataloging-in-Publication Data

Lemire, Elise.

Black Walden : slavery and its aftermath in Concord, Massachusetts / Elise Lemire. p. cm.

Includes bibliographical references and index.

ISBN 978-0-8122-4180-8 (alk. paper)

1. Slavery-Massachusetts - Concord - History. 2. Slaves - Massachusetts - Concord-

Social conditions. 3. Concord (Mass.) - Social conditions - 18th century. 4. Thoreau, Henry

David, 1817-1862. Walden I. Title.

F74.C8L46 2009

974.4'4--dc22

2009001010 
For my parents,

Robert and Virginia Lemire 


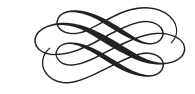

EAST OF MY BEAN-FIELD, across the road, lived Cato Ingraham, slave of Duncan Ingraham, Esquire, gentleman of Concord village; who built his slave a house, and gave him permission to live in Walden Woods; Cato, not Uticensis, but Concordiensis. Some say that he was a Guinea Negro. There are a few who remember his little patch among the walnuts, which he let grow up till he should be old and need them; but a younger and whiter speculator got them at last. He too, however, occupies an equally narrow house at present. Cato's half-obliterated cellar hole still remains, though known to few, being concealed from the traveller by a fringe of pines. It is now filled with the smooth sumach (Rhus glabra,) and one of the earliest species of golden-rod (Solidago stricta) grows there luxuriantly.

Here, by the very comer of my field, still nearer to town, Zilpha, a colored woman, had her little house, where she spun linen for the townsfolk, making the Walden Woods ring with her shrill singing, for she had a loud and notable voice. At length, in the war of 1812, her dwelling was set on fire by English soldiers, prisoners on parole, when she was away, and her cat and dog and hens were all burned up together. She led a hard life, and somewhat inhumane. One old frequenter of these woods remembers, that 
as he passed her house one noon he heard her muttering to herself over her gurgling pot, - "Ye are all bones, bones!" I have seen bricks amid the oak copse there.

Down the road, on the right hand, on Brister's Hill, lived Brister Freeman, "a handy Negro," slave of Squire Cummings once, - there where grow still the apple-trees which Brister planted and tended; large old trees now, but their fruit still wild and ciderish to my taste. Not long since I read his epitaph in the old Lincoln burying-ground, a little on one side, near the unmarked graves of some British grenadiers who fell in the retreat from Concord, - where he is styled "Sippio Brister," - Scipio Africanus he had some title to be called, - "a man of color," as if he were discolored. It also told me, with staring emphasis, when he died; which was but an indirect way of informing me that he ever lived. With him dwelt Fenda, his hospitable wife, who told fortunes, yet pleasantly, large, round, and black, blacker than any of the children of night, such a dusky orb as never rose on Concord before or since. 
